\title{
El Mar y la Costa en Abraham Valdelomar
}

\author{
Por Augujto Tamayo Vargas
}

Los motivos de nuestra costa y de nuestro mar han sido, esporádicamente tratados en la literatura, aunque ya las viejos mitos yungas trazaron en simplesi cuaddros la desnudez del ditoral y la épica hazaña de sus primitivos pobladores. Viracocha, emergiendo de las olas, y Pachacámac, telúrico personaje de arena y roca, hundiendo su figura en los médanos que forman abanicos a la vera del agua salada, caracterizan ya la tragedia que tiene un cíclico desarrollo. Alrededor de ellos están las otras figuras. El semi-dios Con, incorpóreo y extraño ser, que "abajó las montañas", que avanzaban erguidas y altas hacia el mar, para hacer la delgada serpentina costeña, donde germinaron los primitivos hombres en la tierra hinchada. Los riachuelos, que han de correr atemorizados por la superficie perlada que habla de hambre y de soledad. Crecerán, más tardes, las raices, las hierbas y los frutos de los sanguinolentes miembros desgajados del hijo concebido por Viracocha y muerto por Pachacamac, en este combate que constituye la gran fase inicial de nuestra epopeya. Morirán - a la recíprocalos gigantes que creará el dios de arena y serán convertidos en peñoles e islctes, huacas y cerros, como manifestación del poderío del dios del mar. En estos elementos de la preliteratura peruana hay una interpretación cosmogónica y un delinearse de los motivos constitutivos de la zona yunga. Curacas, caciques y mitayos irán forjando luego el resto 
de la historia precalombina, donde se levanta fantasioso el reino de Naylamp o el del viejo Tumbe con las románticas aventuras de Gua. yanay. Mates, golondrinas, pescados, piraguas, arena, agua verdiazul y un horizonte donde los dioses danzan a la caída de la tarde sobre el cielo escarlata. El dios Viracacha se aleja, después, del litora] y se hace personaje serrano, agigantando su silueta en los ocasos del Titicaca; por él se crean las "pacarinas", de donde sale todo lo que vida tiene y encierra, y por él los hombres, nacidos -en esta nueva interpretación mítica- de la piedra andina, corren hacia el ombligo del mundo para forjar el Imperio de los Ayar. El mito lleva a los descendientes de Guayanay a las profundas quebradas de la Sierra y a las Punas de dilatado horizonte, para que bajo el nombre capitán de Manco escriban la página central del pasado peruano. La costa había perdido su primacía. Y la sierra toma para sí el centro de la Cultura, ccn el Cuzco, ombligo y piedra del Imperio.

Las crónicas de la Conquista están hechas de acción y para la acción; todo lo que la Naturaleza encierra de drama permanente no fué sino mero marco descriptivo. Nuestra costa fué pintada como angosta faja de tierras estériles en su mayoría, donde apenas cae una llovizna y donde el mar calmo se encrespa en contadas lugares para barrer la superficie de las playas norteñas o para estallar en furia contra las rocas desafiantes del sura Los poemas de piratas vinieron a traer nuevamente al mar al campo literario Pero su papel fué descolorido e intrascendente. Eran los corsarios atrevidos y los esforzados defensores de las plazas virreinales, los héroes de las acciones cantadas; y el litoral y el océano : escenarios, más no personajes; decoración, pero nunca motivo central, ni figura dialogable. Aurelio Miró Quesada en su ensayo "El Mar : Personaje Peruano", ha hecho una vívida descripción de los episodios marinos relacionados con nuestra país y la significación que tuvieron en el desenvolvimiento de nuestra historia. Acontecer de hechos sobre el mar, pero no acerca del mar. Acaso si en el poema del Conde la Granja, al par que se intenta presentar el valle costeño de Lima se proyecta una acción del mar en las aventuras de los corsarios; novedad entre las amaneradas y densas estrofas del autor de "La Vida de Santa Rosa". Pero ni en él, ni después, se consigue dar carácter al litoral o al mar, hasta que Melgar encuentra ante su vista las notas de inmensidad y abandono, que son eco de su alojamiento de Silvia y de su tormentoso dolor de adolescente. La lírica había murmurado, en cambio, lamentos cordilleranos en los centros culturales mestizos, superviviendo el símbolo de la palo- 
mita y el nido, en los cantares quechuas. Tras Melgar, los románticos giran alrededor de las playas y el mar, soñando en "Occidente"; pero miran en él la reproducción de sus angustias, de poéticos dolores; y la luna presagia sobre el tendido ponto la hora de la desesperación y el trágico desenlace de alguna historia de amor imposible. La playa y el mar son, entonces, escenarios de las quimeras de poetas "sensibles" que se recrean en inventar pasiones atormentadas, imágenes lánguidas - tristes relatos, donde los seres humanos se asemejan generalmente a "frágiles naves al piélago lanzadas". A veces transitan por él tiernas baladas que recuerdan a Goethe, a Víctor Hugo. En cierta ocasión la tragedia hizo efectivamente carne y realidad en "los yermos del mar" sobre un poeta romántico, Manuel Nicolás Corpancho, y Salaverry dijo entonces :

"Fueron de llamas y salobre espuma

Los pliegos de tu sábana mortuoria....";

y más adelante :

"Que importa tu naufragio aquí en la tierra, si flotanto en un verso va tu nombre de una ola en iotrai hastacla edad futura.s. ."

No habría que seguir sino, precisamente a Salaverry, para ver en que forma el mar era una creación del propio espíritu, el mundo interior que el poeta veía reflejado en aquél; puro subjetivismo. La visión del mar en el puerto de Coburgo, en un conocido y magnífico scneto de Salaverry, termina por mostrarle la inmensidad de Dios que surge en su alma. Y, en general, el mar es profundo como su angustia; tormentoso o inmóvil, según las circunstancias; sudario o tumba. En su poema "Inocencia u orgullo", se suman sobre el Océanc, en determinadas estrofas, las notas del amor, de la nostalgia, de la muerte y de persistencia en la niñez que destacan en la poesía de Salaverry. Y asimismo en "La Tumba de mis Sueños" y aun en su extraordinario : "Acuérdate de mi", donde la desolación de su alma, su scledad y su ambición ideal están representadas en esa búsqueda de un nido "entre la mar y el cielo".

Althaus encuentra "camino del cielo la dormida llanura del mar". Palma ve reflejarse en él la congoja juvenil que lo acosa. Es Juan de 
Arona quien lo describe -entre los románticos del Perú- con más precisas notas; lo mira frente a él, no superpuesto a él, ni parte de él; sino ante la vista, en su integridad física, en su propio desenvolverse. Las olas ruedan mansas y dejan sus altos copos de espuma nevada sobre la playa y se retiran y vuelven en majestuoso desarrollo. Al final la nota emotiva deja abierto el camino de la poesía sensible :
"Que era la hora aquella
en que el mar se serena y se reviste
de un azul más profundo y de un aspecto
más solemne y más triste....".

Para nuestra costa tiene también Juan de Arona aciertos descriptivos en sus conocidos "Cuadros y Episodios Peruanos". Los algodonales de Cañete; la bruma de Lima; los contornos de los arenales; el desteñido verde, polvoriento, de muestros valles:

"Con el polvo que los viste aquí el árbol más lozano

arrastra el follaje cano,

y el campo más fresco es triste

como la faz de iun anciano. d"e Letras

Sus poemas "La Costa il ycinal Cosfa Peruana" presentan, con incisivas notas críticas, los pormenores del panorama que "duerme amodorrado al pié del mar". Asoman los médanos, las haciendas costeras, los cantos de "los vigilantes gallos"; los pequeños oasis cultivados en medio de las "arenas, el desierto y los barrancos" que expresa: "del olvido de Dios dan triste muestra". Y añade que nuestra costa es "Africa sin camellos, ni palmas", sin grandes "montes, ríos, árboles ni lagos".

"Pobreza, denudez, contornos vagos.

$Y$ un bello clima, y una dulce calma

que dan la muerte entre embriaguez y halagos....".

Más también manifiesta que él cantará "con metro diferente" la "verde alfombra del maíz naciente", el "vago y apacible colorido" del "Yucal dormido", las lucientes hojas del camotal y la amarilla flor del "rústico zapallo". La obra de Pedro Paz Soldán Unanue es de gran in- 
terés para un estudio de nuestro litoral. Pero su poesía es descriptiva y hecha a la medida del ángulo virgiliano y no hay una interpretación o una expresión de trascendencia, más allá de lo meramente palpable - visible. En tanto crecía un sentimiento y una estética andinas y el elemento aborígen que apareció ya en las páginas precusoras del "Padre Horán", se hace prototipo de novela. La cultura peruana se ha ido galvanizando con la mirada puesta en el sector serrano. Con acierto pasajero o con deficiente perspectiva el escritor sólo busca -en cierto momento- las raíces nacionales dentro de las altas murallas de granitc y tiene la espalda al oeste.

José Santos Chocano en su afán de conseguir una poesía que conjugara con la reclidad histórico-geográfica, cantó los Andes, los cóndores, las punas, por un lado; y las orquideas, las magnolias, la selva enmarañada y trágica, los grandes ríos, por otro. La costa estuvo centralizada en esa poesía entre los linderos de Lima con visiones virreynales, gabernantes galantes, tapadas, evocaciones de la vida colonial. Todo esto dentro de su reconocida retórica poética. Crecian los fermentos de una vuelta literaria a los motivos que iniciara el grupo radical y positivista y el indigenismo hizo cuerpa por sobre la posición académica del 900.

Es en Abraham Valdelomar donde vibraron por sí mismos y con notas peculiares el mar ỷ la costa feruanas. Fué ya interpretación y exégesis, al mismo tiempo. Su obra no quedó, en el campo del ccstumbrismo, de la repetición folklórica, de la cicentuación del llamado carácter criollo o vernacular. El océano y el litoral fueron personajes literarics hechos al diapasón estético o sea en persecución de la belleza, trasrealizando lo visto y lo escuchado con indudable genialidad poética.

Valdelomar no reflejó exactamente la realidad, sino que precisamente su valor estriba en que extrajo de aquella, apariencias significativas; exprimió los detalles para hacer alquitarada expresión. El doctor Marianc Iberico Rodríguez en su estudio sobre "La Transrealidad del Objeto Poético" ha hecho valiosas sugerencias sobre el tema en general. "La poesía - dice- al par que trasciende la inmediata y corpórea realidad del mundo circundante nos entrega un mensaje de profundidad y encierra un sentido de misteriosa identificación del alma con las fuerzas creadoras de la vida y con la oscura fatalidad del destino". Y Valdelomar, eminentemente poético, extrajo de la realidad lo que en ella encontró de belleza, haciendo paréntesis de lo que no significaba nada para su tabulación de valores estéticos. Por ello, el mar y el litcrial fueron estímulos que convertidos en sueños, en visiones de niños, 
en amorosas escenas bucólicas, en motivos de melancólico recuerdo, dieron con la nota crepuscular de su estilo, páginas de delectación artística. El mero dato, la pintura costumbrista, no tuvieron cabida en la prosa, ni en la poesía de Valdelomar. Degustado el objeto poético se convirtió en valor artístico en sí mismo, ajeno a toda referencia exclusivamente localista, y con trascendente contenido universal.

Volviendo nuevamente al citado ensayo del doctor Iberico nos encontramos con el siguiente párrafo que viene precisamente al caso :

"Hay diversos planos de apariencia, planos que se suceden desde el mero contacto sensible - auditivo, visual- con el objeto poético, hasta el oscuro fundamento cntológico de la aparición. La estructura de colores o sonidos que es en sí misma una imagen, evoca otra imagen -que llamaremos significada-la cual despierta acaso una nueva apariencia, y así en número indeterminado hasta el fondo primitivo e inefable. Es como si asistieramos a una serie de refracciones de la apariencia a través de zonas cada yez más profundas del alma, o como si proyectaramos el objetc poético transfigurándolo en término de un creciente lejanía y significación".

Si recogemos el mar de "El Hipocampo de Oro" o de "Los Ojos de Judas"; el sauce solitario, comparado en su insignificancia con la vida de un hombre cualquiera de la aldea; las frutas de las chacras que lindan con la areng geque avanzan hacia lasxibera; el gallo heroico; los motivos costeños que se manifiestan en Yerba Santa", con cantos de mar y playa c entre los nombres dulces de "Verdolaga", apreciaremos que son recogidos - dentro de un método estético- para expresión de lo fundamental : trasunto de sentimiento panteísta, aparición del destino o logro de una acabada forma artística que se convierte en fin en sí misma. El mar y la costa son dos personajes que bullen palpitantes, que dialogan entre nosotros en un mundo que es mitad realidad y mitad sueño, delineando entre formalidades un trascendente mensaje estético. Luis Fabio Xammar, quien ha dado una certera fisonomía y un pespicaz estudio de Valdelomar, dice refiriéndose a "El Caballero Carmelo", por ejemplo: "Este célebre gallo no es sino un alegre pretexto para hacernos partícipes de hondísimas vivencias y de una dulzura cósmica por la existencia....". Pero al par, el tipo se "alza enhiesto e inccmparable", en plena realidad de personaje cumplido. Es esta "novela" motivo para mostrar al poeta y al magnífico prosador, al mismo tiempo. 
"Esbelto, magro, musculoso y austero, su afilada cabeza roja era la de un hidalgo altivo, caballeroso, justiciero y prudente. Agallas bermejas, delgada cresta de encendido color, ojos vivos y redondos, mirada fiera y perdonadora, acerado pico agudo. La cola hacía un arco de plumas tornasol, su cuerpo de color carmelo avanzaba en el pecho audaz y duro. Las piernas fuertes que estacas musulmanas y agudas defendían, cubiertas de escamas, parecían las de un armado caballero medioeval".

Ya se ha dicho que Valdelomar estaba ajeno a todo pintorequismo. En su ensayo "Belmonte el trágico", nos ha de mostrar como concibe la literatura, que no debe obtener el fácil acomodo de la vulgaridad. El éxito ocompaña a los mediocres, sostiene, pero la posteridad se encarga de destruirlos, porque de ellos no queda "una frase, una idea, una observación sobre nada". "El mediocre, sobre un ritmo musical, barato y fácil y por ello universal, ha engarzado ideas baratas, fáciles y universales", afirma dentro de las consideraciones estéticas que sirven como introito al ensayo citado. En ellas manifiesta una teoría sobre "el ritmo" de la obra literaria. De una previa división en tres etapas rítmicas, se desprende que hay uno natural, en que el universo se nos presenta tal cual es, con pureza de líneas, sin emoción ulterior; luego, un ritmo inteligente en que la naturaleza es interpretada por el autor, producto de la razón, búsqueda de imágenes consecuentes, ausencia de la aparición inicial : el ropaje cubre los objetos; y por úlltimo, el ritmo supremo, en que la naturaleza se nos presenta en toda su verdad pavorosa: "es la naturaleza que piensa-dice Valdelomar- es la misma Venus de Milo con las floridas galas de la primavera y con la trágica belleza de la cabeza de Medusa". Vendría a ser esta tercera etapa, una conjunción de las dos primeras manifestaciones, integración de valores. De ahí que Valdelomar se esforzara en mostrarnos la verdad que aparecía tras un crepúsculo al pie del mar, lo que expresaban los guarangos abandonados en los arenales, lo que hay de humano - $y$ de humano a cósmico- en un gallo de pelea $o$ en un caballito de mar, nimbado con el oro de la leyenda y ávido de la copa de sangre, de los ojos y del azahar del durazna que le ofrece año a año la poesía del hombre, para conseguir aquello que en lenguaje platónico se escribiría Amor, con mayúscula.

Tennyson dijo : 
"Golpea, golpea, golpea

en las frías piedras grises, oh mar!....".

Y Valery, un siglo después :

"Sí, mar, gran mar de delirios dotado, piel de pantera y clámide horadada por millares de imágenes del sol, ebria en tu carne azul, hidra absoluta que te muerdes la cola refulgente en un tumulto análogo al sielncio....".

En el primero de los poetas nombrados, el mar traía asociaciones místicas y se veía sobre él caminar las naves hacia el definitivo puerto, mientras las notas crepusculares indicaban que había pasado un día más en el desfile de lo finito a lo infinito. En el segundo, el mar es un motivo de delectación. "El Cementerio Marino" viene a ser una fuente sugerente de imágenes donde se muestran los poliedros del mar con visión y manera poéticas. El océano vive en Tennyson para darnos la idea de un mundo que marcha hacia el más allá, a la bahía inmensa y sombreada al pié de la colina. En Valery es la recreación de lo presente; el mar resulta eterno y trascendente en sí mismo, sin comparación o referencia. 1 Valdelcmar tuvo también presente el paisaje y la palabra del mar. J Lo play a significó su punto de observación y cada reventar de ola o cada ocaso era un motivo de búsqueda estética relacionado con la vida que trascurría en las riberas; ya entre las casas de la aldea - una cualquiera-; ya entre los botes de los pescadores que echan sus velas al alba; o en las arenas donde varan los cadáveres, los huesos de las ballenas y las hierbas marinas y adonde sale a conversar la legendaria figura del "hipocampo de oro". El mar vivía plenamente y el escritor trascribía las mensajes de la Naturaleza en su desgarrante autenticidad. Las horas no marcan el tiempo sino la angustia de las cosas que son estímulo o reflejo de las preocupaciones del hombre. Al oído de éste le hablan la costa y el océano.

"Yo he nacido en el campo y he nacido en abril". La partida de bautizo de Abraham Valdelomar extendida por el cura párroco de la Iglesia Matriz de San Jeronimo de Ica - que reprodujera Xammar en " 3 "- indica su nacimiento autumnal en esa ciudad; y según lo manifestado en ella, el 16 de abril, y no el 27, de 1888. Desde muy niño estraba en Pisco, sobre el litoral. 
Mi infancia, que fué dulce, serena, triste y sola, se deslizó en la paz de una aldea lejana, entre el masno rumor conque muere una ola $y$ el tañer doloroso de una vieja campana.

Dábame el mar la nota de su melancolía; el cielo, la serena quietud de su belleza; los besos de mi madre, una dulce alegría y la muerte del sol una vaga tristeza.

En la mañana azul, al despertar, sentía el canto de las olas como una melodía y luego el soplo denso, perfumado, del mar.

Y lo que él me dijera aún en mi alma persiste; mi padre era callado y mi madre triste y la alegría nadie me la súpo enseñar.......

Valdelomar llega a Lima de Pisco. Dibuja, es periodista; antiacadémico. Colabora en la edición de "Contemporáneos" y "Colónida"; convirtiéndose en realidad, en jefe de un grupo literario. Escribe sus primeros cuentos y obtiene el Premio de "La Nación" de Lima, en 1913. En ellos le hablaban el retazo de campo y Ia monótona vida del villorio. Una dulce melancolía da luz difusa al relato.

En un poema, que corresponde a ese mismo espíritu, dice :

La misma mesa antigua y holgada, de nogal, y sobre ella la misma blancura del mantel y los cuadros de caza de anónimo pincel y la oscura alacena, todo, todo está igual........

Hay un sitio vacío en la mesa hacia el cual mi madre tiende a veces su mirada de miel y se musita el nombre del ausente pero él hoy no vendrá a sentarse en la mesa pascual.

La misma criada pone, sin dejarse sentir, la suculenta vianda y el plácido manjar; pero no hay la alegría ni el afán de reir. 
que animaron antaño la cena familiar;

y mi madre que acaso algo quiere decir,

ve el lugar del ausente $y$ se pone a llorar.........

Hay un tono de ternura hogareña y de paz soleada de pequeña ciudad, que anticipa aquellos melancólicos y sabrosos versos de los primeros años de Vallejo en "Los Heraldos Negros y en "Trilce". El sitio vacío del hermano lejano y la madre que ve el lugar del ausente y se pone a llorar. Sólo que en Valdelomar asoma en su morbidez "la arena que las olas azotan......". La paraca despeina su verde cabellera.... y junto al pescador gira la alba gaviota". En Vallejo hay el color vívido de las serranías y el hombre alza los ojos a la altura, Vallejo busca ansiosamente a Dios; en la costa la vista se torna gris hacia el horizonte.

Valdelomar recorre los elementos que rodean su vida familiar : en "el ñorbo del jardín" hacían "nido los gorriones"; y la "higuerilla", que "se balancea con la brisa marina", tendía sus hojas que él y sus hermanos rozaban "cariñosamente". ... "Las palomas, con sus alas de abanico, eran la nota blanca"... En la playa "verdegueaban las malvas silvestres"... "Palmeras desmedradas", "toñuces coposos y frágiles" vigilaban de "trecho en trecho las entradas del desierto", y a sus pies ondeaba "la hierba del alacrán, verde y jugosa al nacer, quebradiza en sus mejores dias y en la vejez bermeja como sangre de buey". Más allá lás palmeraseformabanelcoro y se abría alguna caleta de pescadores, donde se multiplicaban las higueras, ofreciendo sombra a las gentes sencillas. Valdelomar repasa estampas de esas vidas lentas, en que se entrelazan el pescador abuela que teje las redes con "toscos dedos", "el sorprendido pez", los chiquillos que se "tuestan desnudos al sol", montados sobre el asno "pensativo"; y también los sauces, las gaviotas; naves que se pierden en la neblina con sus gallardos tripulantes; chozas de caña y estera; y en alguna casa del puerto el gallo triunfador "esbelto, magro, musculoso y austero".

A ese mundo de objetos, a esa presentación que podría ser me ramente descriptiva, a ese ambiente, lo traspasa una honda voz lírica, cargada de historia, de encantamiento, de dolorosa melancolía :

Viene de las montañas

un viento frío

$y$ es como sagre de las montañas

el río........ 
Va por el cañaveral

la niña en pos de una rosa

carcomida por el mal;

va por el cañaveral,

silenciosa.....

Y se adelantará muchas veces a Vallejo; en la sombra de los "bueyes" que van desuncidos", "inclinados y vencidos" al remanso, como en "Paz Aldeana" de aquel poeta; o en la comida triste, - desemparo, niñez que vuelve-, con sitios familiares vacías; o en la tristeza y soledad de las horas muertas; y sobre "Heces" o sobre "Pagana" o "Los Anillos Fatigados" pasa un soplo de Valdelomar, que es, por otra parte, justo decirlo, el soplo de una época que en el Perú se llamó "Colónida" y que respondió a las notas de Verlaine, de Samaín, de Rubén, de Silva, y sobre todo de Herrera, en un instante post-modernista. Es todo un movimiento, donde pueden encontrarse elementos de identificación entre Eguren, Bustamante y Ballivián, Ureta, Valdelomar, Vallejo. Clarc está que abundan las diferencias. Sobre todo en Vallejo que se va desprendiendo de la "arquitectura" bella de los otros para llegar a la pura confrontación de la palabra con el sufrimiento, en una nueva belleza formal, donde parece simplemente, que no se encontrara ésta, que resultaran insuficientes las palabras para expresar los complicados estados de ánimo. En Valdelomar persiste la preocupación estética modernista, un afán de palabras hermosas, por su fonéticalo por sü/sentido de expresión; y que Vallejo abandona fácilmente tras los poemas de "Los Heraldos Negros" para convertir su obra en una manifestación de sufrimiento a piel de carne. Sin que debamos creer, por ello, que se alejó de todo "formulismo" poético, pues detrás de todo: ese desprendimiento, hay una "intencionada" fórmula, un preconcebido lenguaje, en nuevo camino de belleza, que hace de Vallejo más un clásico que un romántico. Y no puede negarse que continúan en "España, aparta de mí este cáliz" y en "Poemas Humanos" muchas de las influencias de la juventud : simbolistas franceses, Herrera Reissig y Valdelomar, que deja su huella no sólo en la poesía de Vallejo, sino muy principalmente en los cuentos de éste, que tratan de ajustarse a la técnica de Valdelomar, pero esto no es propiamente tema de este ensayo. Si calamos en ambos, encontraremos que en ellos está sufriendo la Naturaleza entera, a través de dos caracteres distintos, uno plenamente costeño, el otro representativamente andino y que en las dos hay un sentimiento cósmico, agudo, profundo, que en Vallejo se va concentrando en el hombre mismo y en Valdelomar 
se extiende en mucho al medio circundante, al cuadro mismo de la Naturaleza que habla con ricos materiales que se ofrecen $\alpha$ un fino temperamento artístico.

Esos materiales que le ofrece la Naturaleza - su Universo- hablan de cosas diversas, envuelven signos y símbolos que el poeta siente y desentraña con amoroso arte, que tiene blandura de pan aldeano, vibración de puro dolor y colorido de celajes. Dice Valdelomar en una de sus "Neuronas" :

"Tiene la Naturaleza exaltaciones y depresiones. Tiene la Naturaleza instantes de revelación en los cuales se diría que está elocuente. Que habla, que quisiera comunicarse con los hombres. ¿No habéis sentido alguna vez en el campo, en un momento especial é inexplicable, algo que es como la angustia de la Naturaleza, algo extraño que as invita a penetrar en el alma impalpable de las cosas, algo que es como una atracción que ejercen en vosotros fuerzas misteriosas y ocultas? ¿Qué es aquello sino la llamada cariñosa que os hace la madre? ¿No somos por ventura nosotros una parcela de la gran unidad? Creo con toda la fé de que soy dueño, que la Naturaleza ha sido, en un principio, una gram unidad armónica y compleja, que perdió su concreción y que trata de volver a ella".

La Naturalezalestá, pues, diciendo constantemente su "desgarradora verdad".

"A la orilla del mar se piensa siempre -explicaría en uno de sus cuentos-; el continuo ir y venir de las olas; la perenne visión del horizonte, los barcas que cruzan el mar a lo lejos sin que nadie sepa su origen o su rumbo las neblinas matinales, durante las cuales los buques perdidos pitean clamorosamente, como buscándose unos a otros en la bruma, cual ánimas desconsoladas en un mundo de sombras: "Las paracas, aquellos vientos que arrojan a la orilla a los frágiles botes y levantan columnas de polvo monstruosas y livianas; el ruido cotidiano del mar, de tan extraños tonas, cambiantes como las horas; y a veces, en la apacible serenidad marina, al surgir de rugidores animales extraños, tritones pujantes, hinchados, de pequeños ojos y viscosa color, cuyos cuerpos chasquean las aguas al cubrirlos desordenadamente......".

El mar está también reflejado en el mensaje que escriben en las tardes los largos cordones de pájaros sobre el cielo; y en las luces que en la noche se extinguen a la distancia "como vidas estériles". 
La voz de la costa se escucha en el crecer de los sauces "al borde de la parcela colindante" con el yermo; el sauce "Hebaristo", por ejemplo, está rodeado de "yerbasantas" y "llantenes" y por sus raíces corre "el agua fría y turbia de la acequia". Bajo su sombra medita el hombre, simil en la soledad y en el hastio, en el triste acontecer. "La noche envolvía a ambos en el misteric". Los dos "hijos del azar, del capricho y de la sinrazón", esperando inutilmente el florecimiento de las ramas extendidas. Unidos mús tarde - hombre y árbol- en la muerte, envuelto uno por el otro, en el inmenso anonimato de la tierra, que sigue proliferando en derredor. El campo es a veces un simple pedazo de jardín. Y siempre tras el jardín el mar. Por sobre el verde de las higueras y el rojo de las corolas, el plomizo humear de las aves manchando el azul del espacio ó haciendo resaltar la blancura de las gaviotas que flotan a sus costados como copos de espuma. En medio de ambos, del campo que es sólo destellc, menudo ofrecimiento de la tierra, y del mar que es todo inmensidad, está el girón de la playa, donde menudean esqueletos de aves, piedras multicolores, yuyos, sombras de náufragos. Allí sobre la playa, el poeta siente venir la muerte :

"El divino prodigio del silencic...", el ya callado "rumor de las olas", "la inmovilidad....". "Nada acusaba ya a la Humanidad, ni a la vida. Todo era mudo y muerto. Sólo quedaba el zumbido en mi cerebro, que fué extinguiéndose, hasta que sentí el silencio, claro, instantáneo, precisc....". "Jorge Puccinelli Converso"

La muerte llega con menudos pasos de mujer y con silueta blanca. La Muerte ha venido del mar, que él ama tanto; y hacia el mar han de mirar aterrados y fijos "los ojos de Judas", cuya efigie queman implacablemente, todos los años.

"Entre las casas inefables é infinitas que intervienen en el desarrollo de sus leyendas - dice Mariálegui-, con la Fé, el Mar y la Muerte, pone el Crepúsculo. Desde su juventud, su arte estuvo bajo el signo de D'Annunzio. En Italia, el tramonto romano, el atardecer voluptuoso del Janiculum, la vendimia autumnal, Venecia anfibia - marítima y palúdica- exacerbarcn én Valdelomar las emociones crepusculares de "Il Fuoco". Pero a Valdelomar -agrega- lo preserva de una excesiva intoxicación decadentista su vivo y puro lirismo. El "humour", esa nota tan frecuente en su arte, por donde se evade del universo d'annunziano". 
De Wilde tomó la pcse para "epatar" a la burguesía. De $D^{\prime} A$ nnunzio el panteísmo. Mariátegui expone, respecto a su gracia $y$ su novedosa creación, el anticipo pirandelliano de "Hejeristo, el saùce que murió de amor", que según él, muestra : "el fracaso de una existencia, que, en una tentativa superior a su ritmo sórdico, siente romperse su rescrte con grotesco y risible traquido". Pero al lado un color terrígena, indígena.

"Yerbasanta" y "El Hipocampo de Oro", constituyen la alternación de aquellos dos mundos - costa y mar- que se superponen o se enfrentan en Valdelomar, dentro del sentimiento panteísta que ilumina por encima de cualquier nota decadente la obra genial del pceta y del prosador. En una, viven los labradores sobre la eglógica paz de los campos. Recuerdo de "vendimias", de "tambores de pellejo de cabra", de "azahares del pacae", de "la alameda de sauces", del "broquelado pozo". Las niños juegan en los "bosquecillos de toñuces y de pajarobobos". En las noches, el campesino joven, moreno, melancólico, de aldeano amor, canta yaravies :

"En su ventana moría el sol

y abajo lento cantaba el mar;

y ella reía llena de amar,

rubia del oro crepuscular. C.e.".etras

Murmuran las peras en los árboles lentos y altos y murmuran las olas en la ribera próxima. La tierra húmeda y preñada, el desierto y el mar. Entre un mundo de gorriones, de baldes "de dulce leche con calor de madre", de "uvas pintas", transcurre la nunca descubierta tristeza del mozo chacarero quien, al final de la Semana Santa, se aleja par los últimos retazos de la Hacienda, para hundirse definitivamente "en el cerrado misterio tenebroso". Las aguas seguirían debatiéndose bajo el muelle en "las tinieblas" de cada "noche".

En "El Hipocampo de Oro", de una alada y casi diríamos alegre expresión de cuento infantil, surge en toda su esplendidez el mar. En la orilla asoma la palmera cuya copa semeja "la cabellera de una bruja"; se arrastra "la tortuga obesa", que se despierta al grito de las gaviotas y saca "la cabeza chata como el índice de un dardo"...... "dejando caer dos lágrimas por costumbre más que por dolor"..... i y vive Glicina, viuda de algún marino rutilante, blanca "como la leche oleosa de las cocos verdes", y que con ser armoniosa cual "ola antes de reventar", muestra ya una belleza en camino de convertirse en esta- 
tua de mármol. El cuento trascurre sobre la playa y tiene por personajes centrales al "Hipocampo" - rey y símbolo del mar-y a Glicina - espejo de humanidad- en busca del hijo deseado, en persecución de inmortalidad hecha a base de amor y de propio renunciamiento. El océano tiene criaderos de perlas, ejércitos de lacmas, bosques de yuyos, palacios de corales, pero requiere constantemente, para no enceguecer, de nuevos ojos "femeninos", que iluminen las aguas sin fin, de humana sangre que da vida a su cuerpo brillante, y del azahar del del durazno de los dos almendros que brinde el poder de la sabiduría. $Y$ el mar angustiado vive en acecho de satisfacer sus deseos que $\alpha$ cada vencimiento de luna parecen nuevamente inalcanzables. Glicina, a su vez, está para ofrecerle ese placer en compensación del hijo que nazca de sus entrañas - carne y hueso- ó fantasía poética, expresión artística ó tosca obra de artesanía. En el trueque de objetos deseados ambos encuentran la satisfacción de sus deseos, pero ya está naciendo, al ras del gozo, un nuevo despertar de angustias por venir ó el culumbrarse de la propia muerte. El hombre y el mar están otra vez frente a frente; uno para el otro, uno por el otro. "Tado lo que los hombres anhelan está en el fondo del mar", dice el Hipocampo. Pero a la vez, el hombre viene a traerle, al término del período lunar, las ojos, la sangre y la sabiduría, para que en cambio le dupliquen la porción de "amor". Valdelomar eestá confrontando siempre a ambos elementos y él asiste diariamente al espectáculo marino. "¿Te gusta mucho el mar?"... preguntará la muerte. Y el pceta, aún niño, dirá en wrespuesta : "Si, señora; vengo todas las tardes......".

El drama, como género literario, ó sea el dialogar mismo, encontró en "Verdolaga", la superación de otros menores ensayos. Xammar encontró en esta cbra un antecedente a ciertos aspectos del moderno teatro lírico y terrígena de García Lorca. Los nombres de los personajes que huelen a campo y sugieren bellezas en sí solos son ya expresión lírica. Drama eglógico, tiene por escenario la chacra costeña, y por realización una tragedia de pastores. Membrillejo muere al pie del río; y Espigua, la madre, lo busca por cercos y callejones, por el monte y la arena colindante, y lo halla, al fin, con la cabeza en el agua y el cuerpo sobre la grama, con la herida morada, podrido bajo los rayos del sol fuerte. El campo y el mar hacen también plena aparición. Ellos son los verdaderos personajes detrás de Espigua, Membrillejo, Daniela, Moscatel, Agüeda, Maura...... Esta última nos hablará de ellos, pero en verdad son ellos los que hablan por boca de la soñadora: 
"La fruta, la jugosa fruta, la alegre fruta. La fruta no está enferma. La fruta no llora, no tiene dolores, no tiene corazón..... Los árboles, Agüeda, son buenos; los árboles no dañan. ¿Pcrque no te casas con un árbol? Un árbol no te haría sufrir como Claudio. Clauclio te amaba y te hacía sufrir. Tú debes casarte con un árbol. Tú eres Agüeda, la señora Durazno".

En cambio :

"El mar... ¿Cómo es el mar?... Mucha agua, agua salada, amarga, agitada. El agua del mar debe ser salada como las lágrimas......".

"Canción primitiva y pastoril" se le ha llamado. Drama de valle costeño y de mar, podríamos añadir que es "Verdolega", donde los personajes ríen con las flautas de carrizos tiemas y llaran con las viejas cañas que tienen sabor de arena y agua.

Las cosas que lo rodean vibran, en Valdelomar, con la tristeza y la alegría del hombre. Por eso dirá en su "Confiteor";

"Mi alma leñarálel tmundoda alegrią

la Naturaleza vibrará con el temblor de mi corazón, todos serán felices :

el cielo, el mar, los árboles, el paisaje......".

A su conjuro se antropoformizan océano y costa, pez y árbol, y toman definido carácter. Se hacen personajes que tienen representación viva y la Naturaleza se expresa por medio de ellos elocuentemente. Más no son meros símbolos, pues conservan su función y su papel dentro del Universo. El campo destaca bajo el sol ardiente; el mar adquiere su melancólica actitud a la hora "sangrante del crepúsculo". Las aves vuelan como tales al trazar sus signos bajo el cielo, que, a veces, es claramente "abovedado", con "un azul intenso", "como si fuera más grande y más hondo" y los ojos "lo miraran más profundamente". El desierto "vasto, amarillo, monótono, como otro mar de pena y desolación", se extiende a lo largo de lo que la vista alcanza; y el verde de los árboles del valle estrecho y jugoso, es un manchón de alegría sobre la inmensidad. Es la Naturaleza en la tercera etapa del "ritmo". Cada valle costeño es un poema que va a morir al mar, le- 
vantando al paso imágenes de "yerbasantas", de "sauces", de "verdolagas", de "caballeros carmelos" con bermejas agallas, de "señoras blancas" musitando naufragio en las orillas, de haciendas en vendimia y de procesiones con andas de santo lugareño. Al fondo el océano. donde están varadas las embarcaciones que abondonó el viento y donde lucen los faroles al instante del tramonto; en el interior se agitan los peces entre mundos de líquenes y conchaperlas. El hombre es otro poema que se debate entre sus propias desgarramientos y la angustia que le ofrece "su Universo". La Natiraleza, la ternura y el escepticismo fluyen juntos en su prosa y en su poesía :

Amada, ya es hora, ya se acerca la aurora y el cura en la capilla nos espera.

Más tarde, cuando muera la primavera.

Amada, ponte presto los azahares, que ya las luces brillan en los altares y canta el rióblioteca de Letras

-Luego, "amor mío, "Jorge mío, cuando muera el estío.

Amada, nos esperan en la capilla, ponte presto los azahares y la mantilla, porque ya están las rosas en retoño.

-Espera, amado, espera, cuando muera el otoño.

Amada, ponte el velo de desposcrda que cantan las palomas en la enramada su canto tierno.

- Imposible, no esperes;

ya ha llegado el invierno. 
La interpretación del paisaje de la costa peruana constituye, así, seguramente su más preciada veta literaria. Dejemos aparte el fino humor de sus cuentos yanquis, los intentos de literatura incásica, el discutido tema de sus cuentos chincs, las manifestaciones periodísticas donde saltaba el "sonobismo" a lo Wilde, la exaltación de "nuestro señor yo", que imitarían muchos entre nosotros pero sin la genial llamada a la intimidad, al regolasear de la belleza, que se desprende de la obra de Valdelomar; posición que tiene mucho de revolucionaria contra la mediatización burguesa. Tampoco insistiremos en esta ocasión en la técnica y novedad de su prosa entre nosotros.

Nos interesa aquí que fuera admirable intérprete de las voces de la Naturaleza, con un fino sentido de instrumentación artística que le permitió darnos el paisaje de la costa más allá de la copia real, de la simple manifestación eglógica ó de la comparación inmediata; pero no tampoco como ropaje inteligente, como delectación de símbolos ó de metáforas, sino como intento de dar expresión a la voz misma del Universo que estaba hablando para él en cada cosa, en cada animal, en cada accidente natural y en sí mismo. La Naturaleza era un interminable drama en que sus personajes, obedeciendo a fuerzas misteriosas y ocultas; iban en procura de una definitiva concreción armónica. Al lado, la novedad en el giro del impresionismo de la época.

\section{"Jorge Puccinelli Converso"}

Hoy, que está la mañana fresca, azul y lozana; hoy que parece un niño juguetón, la mañana, $y$ el sol parece como que quisiera subir corriendo por las nubes, en la extensión lejana, hoy quisiera reír.........

Hoy, que la noche tiene una trágica duda en que vaga en la sombra una pregunta muda; en que se siente que algo siniestro va $\alpha$ venir, que se baña en el pecho la Tristeza desnuda, hoy quisiera morir......

La muerte llega cuando el mar apenas suena sobre la playa desccnocida, remota, blanca y solitaria. Playa, el fin humano, de todos 
modos, aunque en este caso específico se realice el desenlace entre la cordillera, en ciudad de tejados rojos y campanarios de piedra, muy cerca de la pampa donde quedó sellada la libertad de América.

"Vendrá la muerte un día, con su hoz encarnada nos tenderá los brazos al fin de la jomada.....".

Cuando arribó, Valdelomar estaba en Ayacucho, entre los Andes, el 2 de Noviembre de 1919.

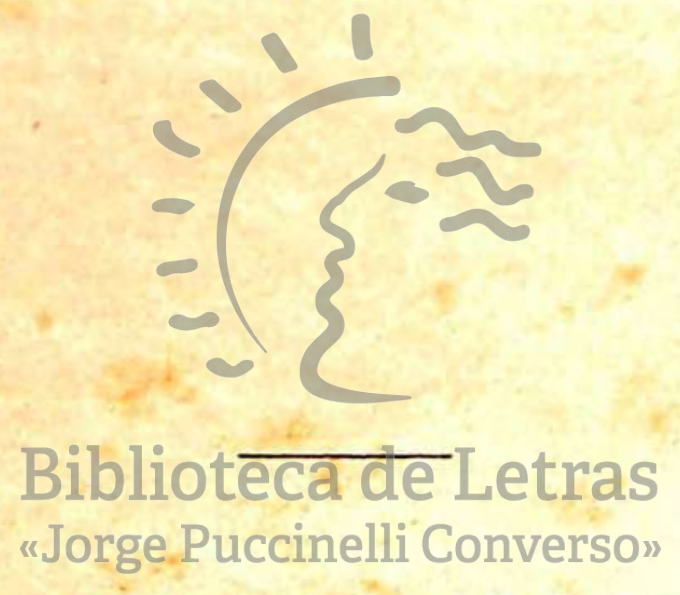

